\title{
Effects of green macroalgal blooms on intertidal sediments: net metabolism and carbon and nitrogen contents
}

\author{
A. Corzo*, S. A. van Bergeijk, E. García-Robledo \\ Department of Biology, Faculty of Marine and Environmental Science, University of Cádiz, 11510 Puerto Real, Spain
}

\begin{abstract}
Eutrophication in coastal areas promotes blooms of green macroalgae that accumulate on the sediment, affecting the exchange of mass and energy at the sediment-water interface. The effects of macroalgal blooms on the microbenthic net metabolism and on the carbon and nitrogen contents of the sediment were studied during an in situ experiment. Two sediment enclosures (with and without macroalgae) of $1.5 \times 1.5 \mathrm{~m}^{2}$ were installed and maintained 2 to 3 wk during every season on an intertidal sediment flat in the Sancti Petri Channel (Bay of Cádiz, Spain) from summer 2002 to spring 2003. Biomass of the macroalgae changed seasonally, with a minimum in winter and a maximum in summer (annual mean: $188.3 \pm 97.3 \mathrm{~g}$ dry wt $\mathrm{m}^{-2}$ ). This relatively low macroalgal biomass always suppressed the photosynthetic activity of microphytobenthos, decreased the oxygen availability for the sediment and reduced the oxygen penetration depth in the light and in the dark. The microbenthic community metabolism clearly shifted to heterotrophic, while the photoautotrophic activity was located in the macroalgal canopy. This macroalgal mat was net autotrophic, and more productive than the microphytobenthic community inhabiting the bare sediment. Part of the macroalgal production was buried in the sediment, increasing its carbon and nitrogen contents with respect to bare sediment during all seasons except spring. Concentrations of inorganic nutrients in the sediment were always higher below the macroalgal mat than in bare sediment, likely due to a direct input of inorganic nitrogen and phosphate associated with macroalgal debris.
\end{abstract}

KEY WORDS: Macroalgal bloom $\cdot$ Microbenthos $\cdot$ Microphytobenthos $\cdot$ Sediment net metabolism $\cdot$ Microelectrodes $\cdot$ Intertidal sediments $\cdot$ Bay of Cadiz

Resale or republication not permitted without written consent of the publisher

\section{INTRODUCTION}

Eutrophication promotes blooms of green macroalgae in estuaries and other shallow environments, which then tend to accumulate on the sediment in large amounts (Valiela et al. 1997). Ulva spp., including the former genera Enteromorpha (Hayden et al. 2003) and Cladophora are the dominant taxa, probably because of their rapid growth rates under high nutrient loading (Valiela et al. 1997). Macroalgal blooms are a widespread phenomenon that affects ecosystem structure and function in different ways. They have been shown to negatively affect other benthic communities like seagrass beds (Den Hartog 1994), microbenthic communities (Sundbäck et al. 1990, 1996) and macrofauna (Norkko \& Bonsdorff 1996). Major and more obvious effects are due to light attenuation for underlying photosynthetic communities and the generation of hypoxic or anoxic conditions. This leads to the production and accumulation of hydrogen sulphide in dense macroalgal mats and in the sediment below the mat (Nedergaard et al. 2002, Lomstein et al. 2006).

In estuaries and shallow water bodies, the sediment plays an important role in local biogeochemical cycles. Photosynthetic activity of microphytobenthos may account for a large portion of the total primary production in these environments (MacIntyre et al. 1996), and therefore represents an important carbon source for 
benthic heterotrophs (Middelburg et al. 2000). In addition, biological activities of microbenthos play an important role in the oxygen and nutrient availability of the sediment-water interface affecting the mineralisation of organic matter and the cycling of elements (Risgaard-Petersen 2003). Growth and deposition of macroalgal blooms at the sediment surface have been shown to affect the microphytobenthos and the nutrient net exchange at the sediment-water interface (Sundbäck et al. 1990, 1996, Lavery \& McComb 1991). This is a particularly complex process because the macroalgal biomass not only represents a large additional source of organic matter, but this biomass is physiologically active as well and is likely to compete with microphytobenthos for light and inorganic nutrients. Moreover, the physiological activity and growth rate of macroalgal blooms change seasonally, and their effects on the net exchange of oxygen and nutrients at the sediment-water interface are likely to change accordingly.

The general aim of the present study was to analyse the effects of blooms of green macroalgae on the intertidal microbenthic community of bare sediment in situ, particularly their biogeochemical consequences. We tested 3 specific hypotheses: (1) macroalgae might inhibit microphytobenthos (MPB) photosynthetic activity, changing the net metabolism of the microbenthic community to net heterotrophic; (2) the expected changes in the net metabolism might affect the rates and pathways of organic matter mineralisation, stimulating anaerobic metabolism like sulphate reduction; and (3) macroalgae are likely to affect the $\mathrm{C}$ and $\mathrm{N}$ content of intertidal sediments, both directly, being themselves a source of organic and inorganic nutrients for the sediment, and/or indirectly, by affecting relevant processes in the $\mathrm{C}$ and $\mathrm{N}$ biogeochemical cycles (as a consequence of Points 1 and 2). We show, at microscale, how the presence of macroalgae at the sediment surface alters the net exchange of oxygen at the sediment-water interface and the content of carbon, nitrogen and inorganic nutrients of intertidal sediments by comparing 2 experimental in situ enclosures with and without macroalgae during the 4 seasons. Our contribution represents one of the first in situ experimental studies addressing the effect of macroalgal blooms on the ecology of microbenthos.

\section{MATERIALS AND METHODS}

Study site, experimental design of in situ experiments and samples of macroalgae. Measurements were performed on intertidal sediments at the Sancti Petri Channel (36² $5^{\prime} 23.5^{\prime \prime} \mathrm{N}, 6^{\circ} 12^{\prime} 53.8^{\prime \prime} \mathrm{W}$, Bay of Cádiz, Spain), from July 2002 to May 2003 (Fig. 1). The

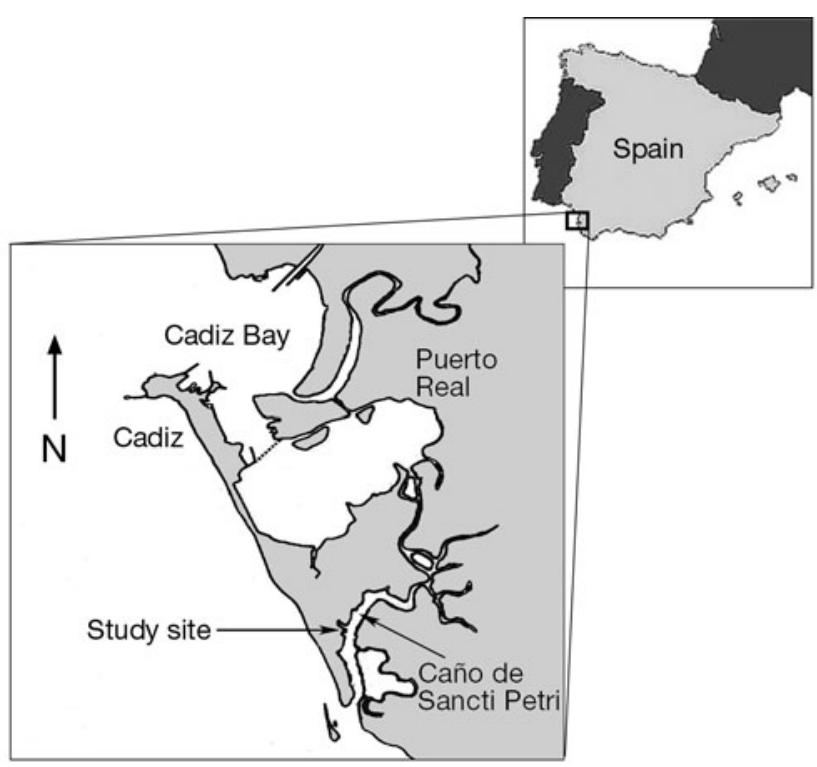

Fig. 1. Geographical location of the study site

Bay of Cádiz is influenced by a semi-diurnal tidal cycle, with a mean tidal amplitude of $2.2 \mathrm{~m}$. At the sampling site, the sediment was mainly composed of silt and clay, since $>90 \%$ of the particles were $<63 \mu \mathrm{m}$. During each season (July and November 2002 and February and May 2003), 2 enclosures $\left(1.5 \times 1.5 \mathrm{~m}^{2}\right.$, $2 \mathrm{~m}$ height) with and without macroalgae were installed at randomly selected locations and maintained for 2 to $3 \mathrm{wk}$ to avoid displacement of macroalgae during the sampling period and therefore possible changes in the environmental conditions of the sediment. The enclosures consisted of a frame of PVC tubes and a plastic netting with a mesh size of $2 \mathrm{~cm}$ placed on the sediment. The plastic netting was put only on the sides of the frame, and thus the top and bottom were open. The upper edges of the enclosures were always higher than the height of spring tide. Field work started at least a week after establishment of the enclosures.

The macroalgae consisted mainly of tubular Ulva spp. (the former genus Enteromorpha; Hayden et al. 2003) partially attached to sediment. Biomass density of the macroalgae was determined by cutting out 2 randomly chosen squares of sediment $(10 \times 10 \mathrm{~cm})$ with a knife. The samples were transported to the laboratory on ice. The macroalgae were washed with seawater from the sampling site, rinsed with filtered seawater (GF/F Whatman) and finally were wiped dry gently with tissue paper. Dry weight (DW) was determined after 24 to $48 \mathrm{~h}$ at $60^{\circ} \mathrm{C}$.

Inorganic nutrients. Inorganic nutrients (nitrate, nitrite, ammonium and phosphate) were measured in 
the water column, in the macroalgal biomass and in the sediment. Inorganic nutrients in the water column were determined in triplicate samples collected during day time and high tide at a distance of 1 to $10 \mathrm{~m}$ from the enclosures. The samples were transported to the laboratory on ice and were filtered over glass fibre filters (GF/F Whatman) and stored at $-20^{\circ} \mathrm{C}$ until analysis on a Technicon Traacs 800 autoanalyser following standard protocols (Grasshoff et al. 1983).

Intracellular inorganic nutrients were extracted according to Corzo \& Niell (1992). A Powder of dry, homogenised macroalgae $(0.05 \mathrm{~g})$, obtained from the samples taken for biomass density, was incubated in $4 \mathrm{ml}$ of Milli-Q water at room temperature for $2 \mathrm{~h}$. Extracts were centrifuged at $3000 \times g$ for $10 \mathrm{~min}$, and inorganic nutrients were measured in the collected supernatant using a TRAACS-800 autoanalyser.

Freeze-lysable inorganic nutrients in the sediment were measured as follows. Five sediment cores (internal diameter [i.d.] $=1.6 \mathrm{~cm}$ ) were randomly collected from both enclosures every season. Sediment slices of $1 \mathrm{~mm}$ thickness were immediately cut with a razor blade from every core. Slices of the same depth from each enclosure were pooled in a plastic screw-cap tube, frozen in liquid nitrogen and stored at $-80^{\circ} \mathrm{C}$. The samples were thawed overnight at $1^{\circ} \mathrm{C}$ and centrifuged for $30 \mathrm{~min}$ at $2350 \times g$ and $4^{\circ} \mathrm{C}$ to extract interstitial water. Nutrient concentrations in the extracted interstitial water were measured using a TRAACS-800 autoanalyser. This method extracts both pore water nutrients and intracellular nutrients from the sediment microbiota (Lomstein et al. 1990, Sayama 2001, Ferguson et al. 2004).

Microelectrode measurements. Sediment cores from both enclosures were collected during low tide with Plexiglas tubes (i.d. $=5.6 \mathrm{~cm}$ ). They were quickly transported to the laboratory and mounted in a temperature-controlled flow chamber, where microelectrode measurements were performed (Lorenzen et al. 1995). The chamber was continuously flushed with filtered seawater from the sampling site at in situ temperature and a flow velocity of about $0.5 \mathrm{~cm} \mathrm{~s}^{-1}$. Vertical steady-state profiles of oxygen, $\mathrm{pH}$ and sulphide were measured with microelectrodes in the cores incubated in the dark and in the light at a constant photon flux density (PFD) of $1000 \mu \mathrm{mol}$ photons $\mathrm{m}^{-2} \mathrm{~s}^{-1}$ (halogen lamp, Novaflex, World Precision Instruments). We checked that photosynthetic activity was saturated at this PFD according to photosynthesis-irradiance curves (results not shown) obtained by pulse amplitude modulated (PAM) fluorimetry (PAM 2000, Waltz).

Oxygen, pH and sulphide microelectrodes were purchased from Unisense. The oxygen sensors (Revsbech 1989) had a tip diameter of 20 to $30 \mu \mathrm{m}$, a response time of 0.2 to $0.4 \mathrm{~s}$, and a stirring sensibility $<2 \%$. Lin- ear calibration was performed by considering the well oxygenated overlying water in the flow chamber to represent $100 \%$ saturation of $\mathrm{O}_{2}$ and the anoxic layer inside the sediment to represent $0 \%$ saturation. Sulphide and $\mathrm{pH}$ microelectrodes had a tip diameter similar to that of the oxygen microelectrodes and were used and calibrated as reported elsewhere (Kühl et al. 1998, Corzo et al. 2005a). Total sulphide $\left(\mathrm{H}_{2} \mathrm{~S}\right)$ was calculated from dissolved sulphide and $\mathrm{pH}$ (Kühl et al. 1998). Oxygen and sulphide microlectrodes were connected to a highsensitivity picoammeter (Unisense PA2000), and the $\mathrm{pH}$ microlectrode was connected to a high-impedance $\mathrm{mV}$-meter (Meterlab). The signals from the picoammeter and the $\mathrm{mV}$-meter were registered by a strip chart recorder. Microelectrodes were mounted in a mechanical micromanipulator (Unisense) and were driven down into the sediment or the macroalgal mat with a step resolution of $100 \mu \mathrm{m}$.

Oxygen fluxes across the sediment-water interface, net production $\left(P_{\mathrm{n}}\right)$ and dark respiration $\left(R_{\mathrm{d}}\right)$ were calculated from the oxygen profiles in the light and in the dark, respectively, using the equation of Fick's first law of diffusion according to Revsbech \& Jørgensen (1983). The molecular diffusion coefficient $\left(D_{0}\right)$ was obtained from in situ salinity and temperature from every season with the help of tables published online by Unisense (www.unisense.com). $D_{\mathrm{o}}$ values used in our calculations ranged between $1.7467 \times 10^{-5} \mathrm{~cm} \mathrm{~s}^{-1}$ (February 2003) and $2.2239 \times 10^{-5} \mathrm{~cm} \mathrm{~s}^{-1}$ (May 2003). Vertical profiles of gross photosynthesis rate $\left(P_{\mathrm{g}}\right)$ were measured by the light-dark shift technique and integrated over depth to produce areal rates (Revsbech \& Jørgensen 1983, Glud et al. 1992).

Carbon and nitrogen contents. Total carbon (C) and total nitrogen $(\mathrm{N})$ contents of the sediment and of the macroalgal canopy were measured using an elemental analyser (LECO CHNS 932). Three replicate sediment cores $($ i.d. $=1.6 \mathrm{~cm}$ ) were sliced in 2 layers, 0 to 2.5 and 2.5 to $5 \mathrm{~mm}$. The slices were dried $\left(60^{\circ} \mathrm{C}\right)$, homogenised and stored frozen at $-20^{\circ} \mathrm{C}$ until their analysis. Subsamples of the macroalgae collected for the determination of macroalgal biomass were used to determine tissue content of $\mathrm{C}$ and $\mathrm{N}$ (Corzo \& Niell 1991).

To ease the comparison of the impact of macroalgae on $\mathrm{C}$ and $\mathrm{N}$ contents and the $\mathrm{C}: \mathrm{N}$ ratio of the sediment, we normalised these variables as follows:

$$
I_{X}=\frac{X_{\mathrm{M}}-X_{\mathrm{C}}}{X_{\mathrm{C}}} \times 100
$$

where the impact of macroalgae on any $X$ parameter $\left(I_{X}\right)$ has been calculated as the difference between the value of $X$ in the macroalgal covered sediment $\left(X_{\mathrm{M}}\right)$ and its value in the control sediment $\left(X_{C}\right)$, normalised to the last value. 
Statistical analysis. Differences between variables due to the presence/absence of macroalgae or due to seasonal changes were tested by 1-way analysis of variance (ANOVA). Comparisons of 2 means were done using Student's $t$-test. Statistical analyses were performed using the software Statgraphics Plus 5.1. All means are given with $\pm \mathrm{SD}$, unless stated otherwise.

\section{RESULTS}

\section{Macroalgal biomass}

Macroalgal biomass (annual mean: $188.3 \pm 97.35 \mathrm{~g}$ DW $\mathrm{m}^{-2}$ ), consisting mainly of tubular Ulva spp., changed seasonally, with minimum and maximum values observed in winter and summer, respectively (Fig. 2A). Annual biomass changes were linearly correlated to changes in temperature $\left(\mathrm{r}^{2}=0.659, \mathrm{p}<0.05\right)$, but were not correlated to changes in the concentration of nutrients in the water column $(p>0.05)$. Inorganic nutrient concentrations were low during the annual cycle, always $<7 \mu \mathrm{M}$. Nitrate, nitrite and ammonium peaked in winter (Fig. 2B).

Carbon and nitrogen contents of macroalgae increased during the studied period, but the increase in $\mathrm{N}$ was higher, since the $\mathrm{C}: \mathrm{N}$ ratio decreased during the spring of 2003 (Fig. 3A). Macroalgae mainly stored inorganic nitrogen, in the form of nitrate, during autumn, up to $108.7 \pm 28.3 \mu \mathrm{mol} \mathrm{g}^{-1} \mathrm{DW}$ (Fig. 3B). Minimum contents of inorganic nitrogen were observed in summer.

\section{Oxygen concentration and net metabolism at the sediment-water interface}

The intertidal microbenthos was photosynthetically active in all 4 seasons in the control enclosures, which was shown by the difference in oxygen distribution at the sediment-water interface in the light and in the dark (Figs. $4 \&$ 5). Oxygen penetration depth in the dark was $0.56 \pm 0.16 \mathrm{~mm}$, while in the light it reached $2.48 \pm 0.45 \mathrm{~mm}$ (Table 1). This community was net autotrophic in every season, since $P_{\mathrm{n}}$ was always positive (Fig. 6). $P_{\mathrm{g}}$ ranged between $8.6 \pm 6.3$ and $24.3 \pm$ $4.8 \mathrm{mmol} \mathrm{O}_{2} \mathrm{~m}^{-2} \mathrm{~h}^{-1}$. Minimum $P_{\mathrm{g}}$ and $P_{\mathrm{n}}$ rates were observed in autumn, and maximum values were observed in spring; however, the differences among seasons were not statistically significant $(\mathrm{p}>0.05$, ANOVA). Similarly, seasonal changes in $R_{\mathrm{d}}$ were not significant ( $p>0.05$, ANOVA); the annual mean was $2.5 \pm 0.9 \mathrm{mmol} \mathrm{O}_{2} \mathrm{~m}^{-2} \mathrm{~h}^{-1}$ (Fig. 6, Table 1).

The presence of macroalgae increased the extension and complexity of the benthic-pelagic interface, as compared with bare sediment, leading to irregularly
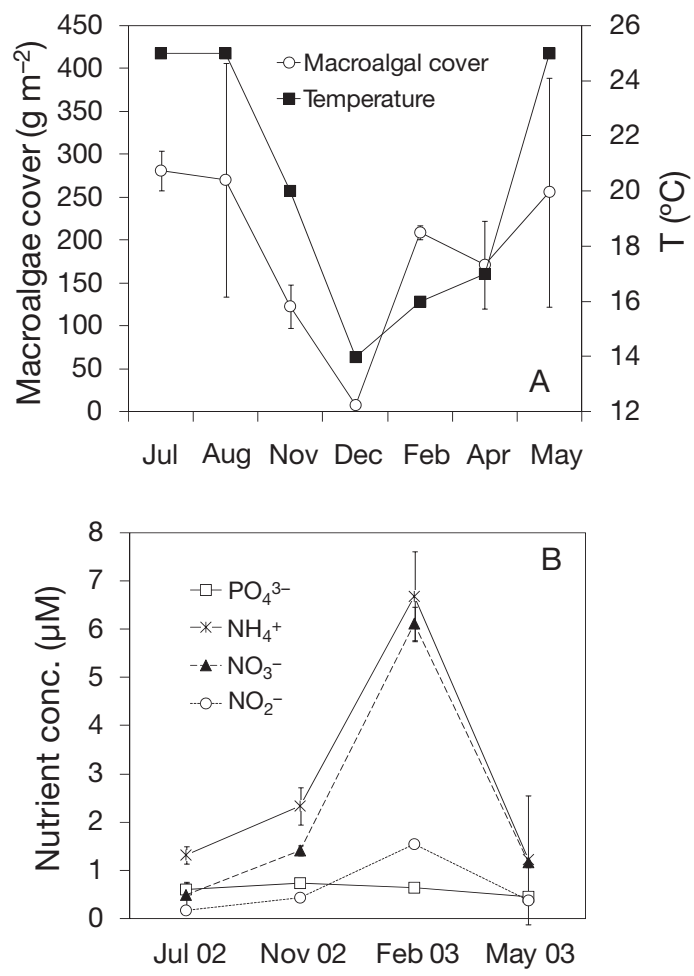

Fig. 2. (A) Annual changes in macroalgal biomass and water column temperature, and (B) nitrate, nitrite, ammonium and phosphate concentrations in the water column. Data are means $\pm \mathrm{SD}$ (error bars) ( $\mathrm{n}=2$ to 3 )

shaped oxygen profiles in the light and the dark (Figs. 4 \& 5). Macroalgae were always photosynthetically active, since the differences between the $\mathrm{O}_{2}$ profiles in the light and in the dark were evident during all seasons (Figs. 4 \& 5). Gross photosynthesis rates changed seasonally from $21.4 \pm 11.7$ to $59.4 \pm$ $22.7 \mathrm{mmol} \mathrm{O}_{2} \mathrm{~m}^{-2} \mathrm{~h}^{-1}$, with maximum rates observed in February (Fig. 6A). Average gross primary production increased significantly from $18.7 \pm 8.4$ in bare sediment to $32.9 \pm 19.4 \mathrm{mmol} \mathrm{O}_{2} \mathrm{~m}^{-2} \mathrm{~h}^{-1}$ with macroalgae (p $<0.03, t$-test). $P_{\mathrm{n}}$ and $R_{\mathrm{d}}$ of the macroalgal mat were lower than the values for the same parameters measured for the microbenthos in bare sediment (Table 1). However, as we will discuss later, we believe that $P_{\mathrm{n}}$ and $R_{\mathrm{d}}$ might be severely underestimated when calculated from the oxygen gradient at the diffusive boundary layer (DBL) between the mat and the water column.

Macroalgae fully suppressed the photosynthetic activity of microbenthos in all seasons; therefore, net metabolism of the microbenthic community shifted to heterotrophic (Figs. $4 \& 5$, Table 1). In addition, the effect of macroalgae on the oxygen exchange at the sediment-water interface depended on light availability. During the dark period, oxygen was fully ex- 


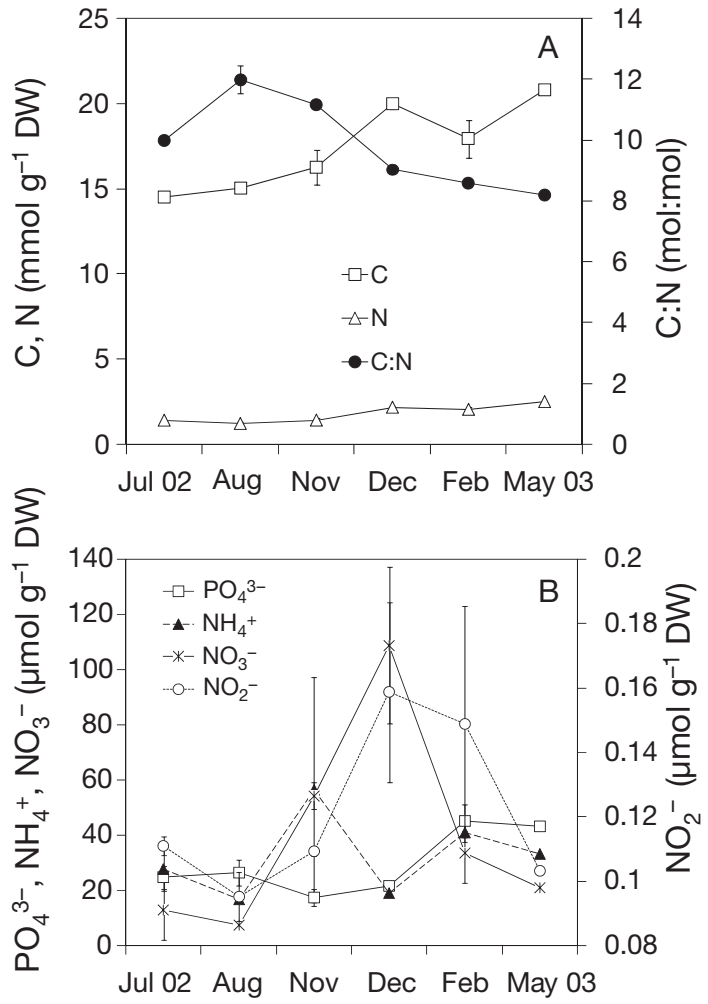

Fig. 3. (A) Annual changes in total $\mathrm{C}$ and $\mathrm{N}$ contents and the $\mathrm{C}: \mathrm{N}$ ratio of macroalgae, and (B) tissue contents of inorganic nutrients. Data are means $\pm \mathrm{SD}$ (error bars) ( $\mathrm{n}=2$ to 3 ). DW: dry weight

hausted inside the macroalgal mat in about $30 \%$ of the measured profiles (mainly in July 2002), demonstrating that anoxic conditions can develop daily within the mat even at moderate biomass (Fig. 5). Macroalgae considerably reduced $R_{\mathrm{d}}$ at the sediment-water interface in the dark $(p<0.01, t$-test). However, the decrease in the oxygen penetration depth was not significant with respect to the control (Table 1). In the light, the concentration of $\mathrm{O}_{2}$ within the mat and close to the sediment surface was frequently equal to or higher than the concentration in the bulk water, due to the photosynthetic activity of the macroalgae. Therefore, macroalgae inhibited the $P_{\mathrm{g}}$ of microphytobenthos, but increased the aerobic respiration of the sediment, producing a negative net production similar to that found in bare sediments in the dark $\left(-2.6 \pm 1.9 \mathrm{mmol} \mathrm{O}_{2} \mathrm{~m}^{-2}\right.$ $\mathrm{h}^{-1}$; Fig. 6B, Table 1). Under these conditions, macroalgae reduced the oxygen penetration depth in the sediment to $0.96 \pm 0.54 \mathrm{~mm}$ in the light $(\mathrm{p}<0.01, t$-test; Table 1, Fig. 5).

Sulphide was never detected in the control enclosures, although it was found in the sediment below the macroalgal mat in some samples (Fig. 4). In these cases, the sulphide concentration was higher in the dark than in the light.

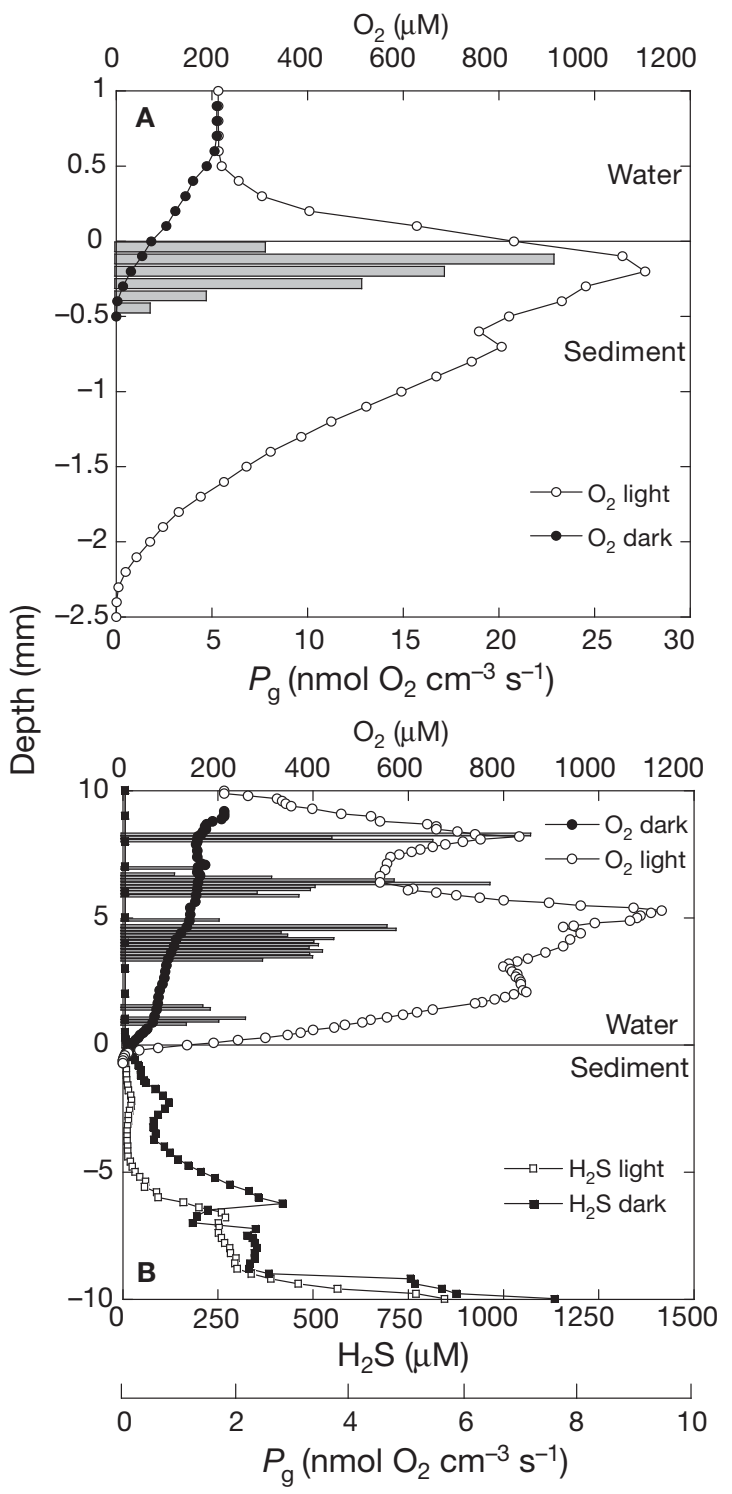

Fig. 4. Representative vertical profiles of (A) $\mathrm{O}_{2}$ at the sediment-water interface in bare sediment and (B) $\mathrm{O}_{2}$ and $\mathrm{H}_{2} \mathrm{~S}$ in sediment covered with macroalgae in February 2003. Gross photosynthesis rates are represented by bars at different depths. $P_{\mathrm{g}}$ : gross primary production

\section{$\mathrm{C}$ and $\mathbf{N}$ contents of the sediment}

The total carbon content of sediment decreased significantly with depth $(\mathrm{p}<0.01$, ANOVA), but no significant differences were observed for total nitrogen or the C:N ratio between depths (Fig. 7). The presence of the macroalgae significantly increased the mean annual $\mathrm{C}$ and $\mathrm{N}$ contents of the sediment $(\mathrm{p}<0.01$, ANOVA). However, the increase in $\mathrm{N}$ was higher, leading to a significant decrease in the $\mathrm{C}: \mathrm{N}$ ratio $(\mathrm{p}<0.01$, ANOVA $)$.

The effect of macroalgae on the $\mathrm{C}$ and $\mathrm{N}$ contents and the $\mathrm{C}: \mathrm{N}$ ratio of the sediment changed seasonally 

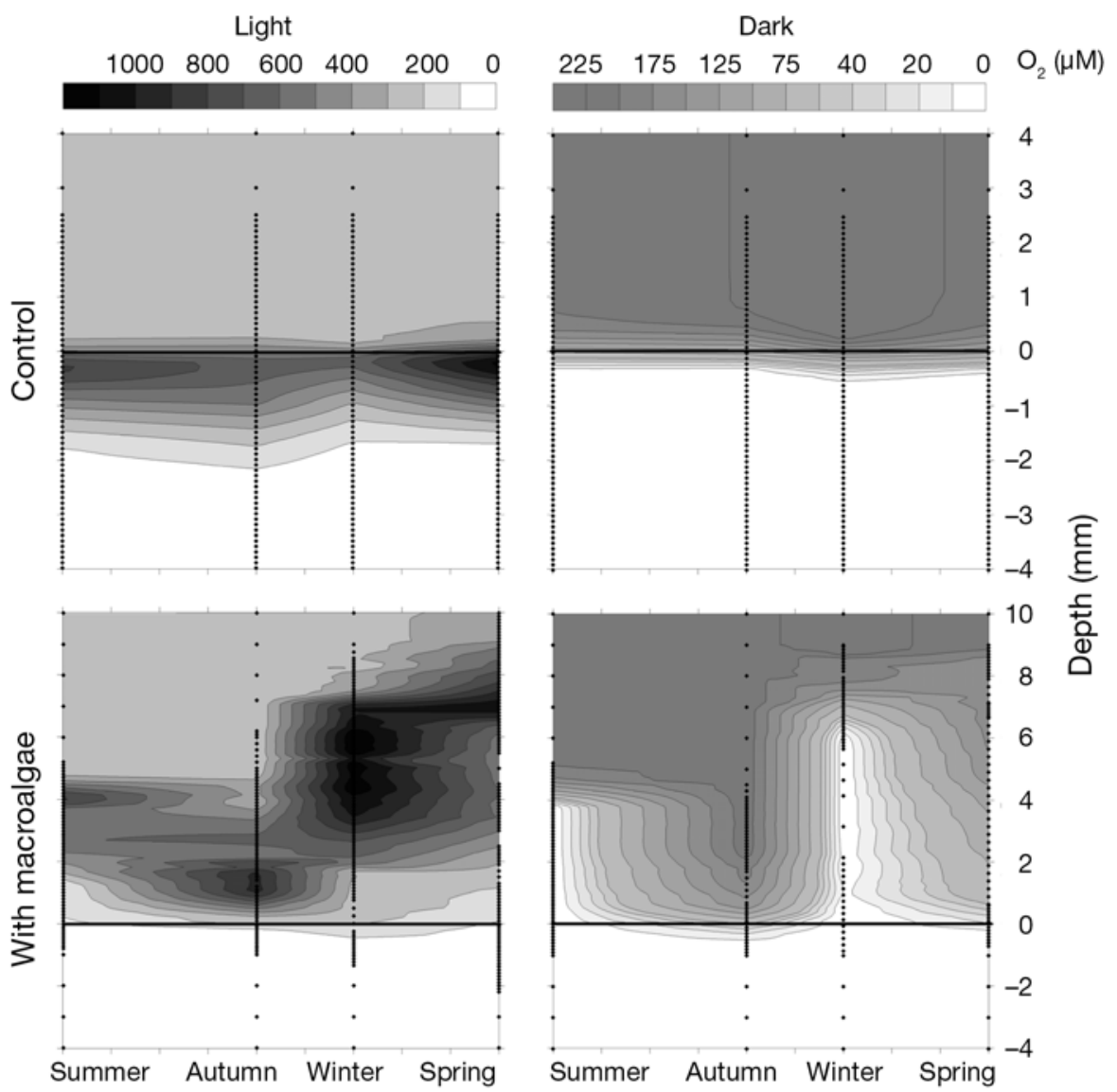

Fig. 5. Contour plot of $\mathrm{O}_{2}$ at the sediment-water interface during the annual cycle in bare sediment (control) and in sediment covered with a macroalgal mat, in the light and in the dark. Data are means of 4 profiles

$(\mathrm{p}<0.01$, ANOVA). The effect of macroalgae on $\mathrm{C}$ was positive during all seasons, except for spring, at which time the microbenthos in absence of macroalgae contained more $\mathrm{C}$ than under the macroalgal canopy (Fig. 8). A similar response was observed for the N content in the upper $2.5 \mathrm{~mm}$, although it increased less than C (Fig. 8).

Table 1. Rates of gross primary production $\left(P_{\mathrm{g}}\right)$, net production $\left(P_{\mathrm{n}}\right)$ and dark respiration $\left(R_{\mathrm{d}}\right)$ of the macroalgal canopy and microbenthos inhabiting bare sediment and sediment covered with macroalgae. Data were obtained from oxygen microelectrode measurements during the annual cycle (expressed as $\mathrm{mmol} \mathrm{O}_{2} \mathrm{~m}^{-2} \mathrm{~h}^{-1} \pm$ $\mathrm{SD} ; \mathrm{n}=10$ to 16$)$. The oxygen penetration depths (mm) within the sediment in the dark and in the light are also presented. Note that $P_{\mathrm{g}}$ is not equal to $P_{\mathrm{n}}+R_{\mathrm{d}}$ because the respiration rate in the light is much higher than $R_{\mathrm{d}}$. -: not applicable

\begin{tabular}{|lccccc|}
\hline & \multirow{2}{*}{$P_{\mathrm{g}}$} & $P_{\mathrm{n}}$ & \multirow{2}{*}{$R_{\mathrm{d}}$} & \multicolumn{2}{c|}{$\mathrm{O}_{2}$ depth mm -} \\
& & & & Dark & Light \\
\hline Bare sediment & $18.7 \pm 8.4$ & $11.0 \pm 4.4$ & $2.5 \pm 0.9$ & $0.6 \pm 0.2$ & $2.5 \pm 0.4$ \\
Covered sediment & 0 & $-2.6 \pm 1.9$ & $0.3 \pm 0.3$ & $0.5 \pm 0.5$ & $1.0 \pm 0.5$ \\
Macroalgae & $32.9 \pm 19.3$ & $3.9 \pm 2.6$ & $1.1 \pm 0.7$ & - & - \\
\hline
\end{tabular}

\section{Accumulation of inorganic nutrients in the sediment}

Concentrations of freeze-lysable inorganic nutrients in the bare sediment changed considerably during the year (Fig. 9A-D). Maximum concentrations in the upper $1 \mathrm{~mm}$ of bare sediment were observed in summer and autumn. The general pattern reflected maximum concentrations at the sediment surface and a steep decrease with depth in the upper $2 \mathrm{~mm}$, both in bare sediment and in the presence of macroalgae. Ammonium was the dominant species of inorganic nitrogen in the upper millimetres of bare sediment, it ranged between 319 and $1209 \mu \mathrm{M}$. The nitrate concentration changed from 18 to $84 \mu \mathrm{M}$, and the nitrite concentration, from 2 to $7 \mu \mathrm{M}$. Phosphate ranged from 34 to $118 \mu \mathrm{M}$. Macroalgae increased the content of inorganic nutrients in the sediment. The effect of macroalgae on every inorganic 

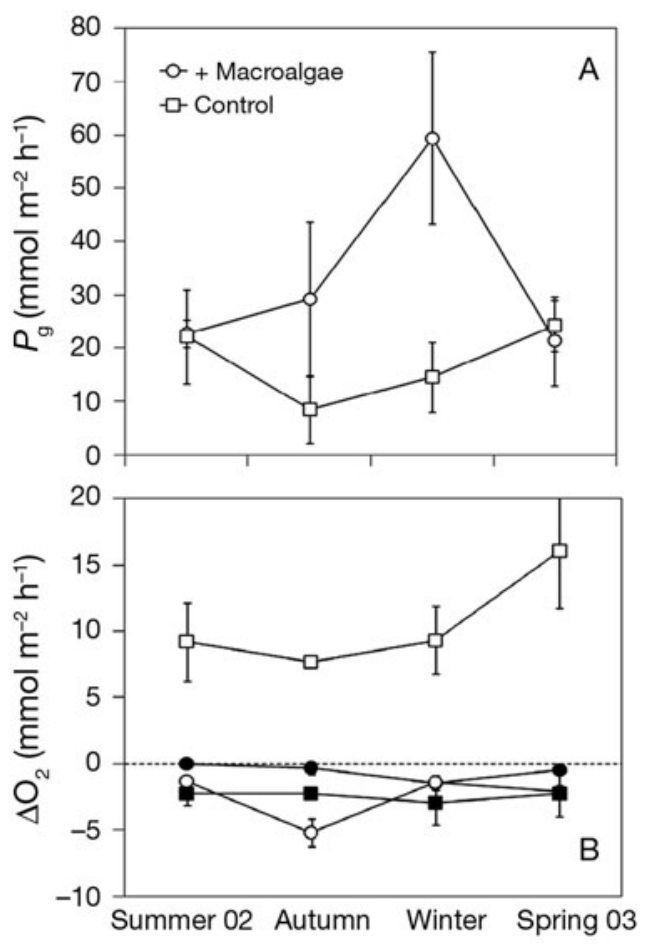

Fig. 6. (A) Gross primary production $\left(P_{\mathrm{g}}\right)$ of macroalgae (+ macroalgae) and in bare sediment (control). (B) $\mathrm{O}_{2}$ exchange at the sediment-water interface. $\square$ : net primary production of bare sediment in the light; $\mathbf{\square}$ : dark respiration of bare sediment; $\mathrm{O}$, $\bullet$ : sediment respiration below the macroalgal canopy in the light and in the dark, respectively. Data are means $\pm \mathrm{SD}$ (error bars) $(\mathrm{n}=4)$

nutrient was quantified as the difference between the concentration in the sediment covered with macroalgae and the concentration in the bare sediment for every depth and season (Fig. 9E-H). The effect of macroalgae decreased with depth; the maximum differences were observed in the upper $2 \mathrm{~mm}$ of sediment for nitrate and phosphate during summer and autumn. Particularly, very large nitrate concentrations were observed in autumn. Macroalgae had major effects on the ammonium and nitrite values measured in summer and autumn as well. However, maximum differences were observed below the sediment surface, at a depth of 2 to $3 \mathrm{~mm}$ for ammonium and 5 to $6 \mathrm{~mm}$ for nitrite (Fig. 9).

\section{DISCUSSION}

\section{Limitations of the experimental design}

The experimental design includes (1) an unreplicated experiment for each season, since only a control and 1 set of treatment enclosures were used for each season due to logistic limitations, and (2) a replicated experiment on an
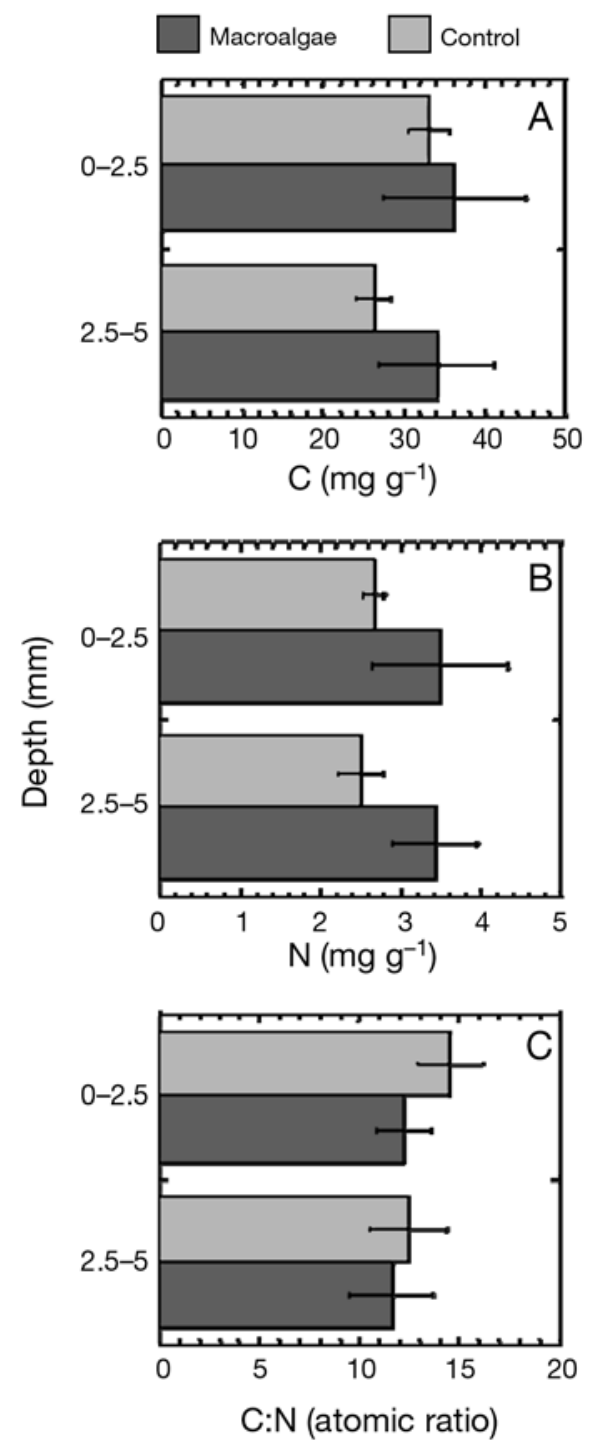

Fig. 7. Annual means of (A) total carbon, (B) total nitrogen and (C) the $\mathrm{C}: \mathrm{N}$ ratio of the sediment in the absence (control) and in the presence of macroalgae in 2 layers of sediment ( 0 to 2.5 and 2.5 to $5 \mathrm{~mm})$. Error bars are SD $(\mathrm{n}=12)$

annual scale because the same experiment was independently repeated 4 times during the year in randomly selected plots at our study site. Therefore, inferential statistics can legitimately be applied to annually averaged data, but not to the seasonal trends. Statistics were used in the latter case only to better describe the differences between both enclosures and to take into account the spatial heterogeneity within each enclosure.

\section{Biomass and chemical composition of macroalgae}

Seasonal variability in standing stocks, growth rate and chemical composition of macroalgal biomass has 


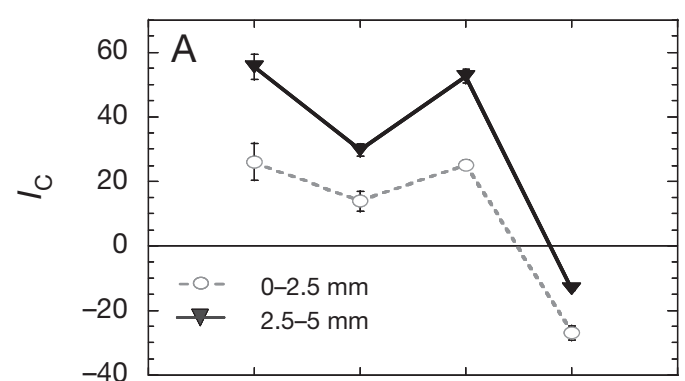

Summer Autumn Winter Spring
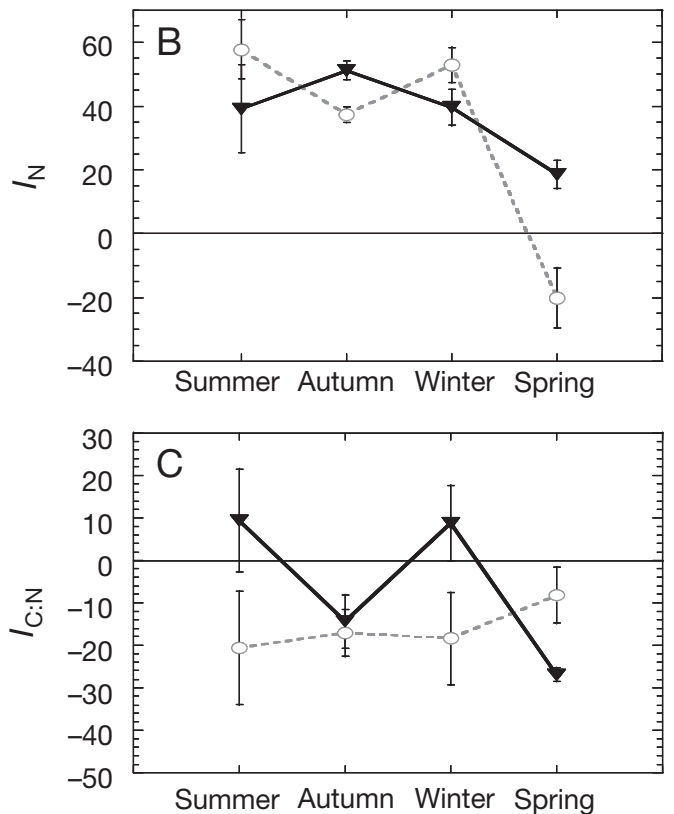

Fig. 8. Seasonal change of the effect of macroalgae on (A) total carbon $\left(I_{\mathrm{C}}\right),(\mathrm{B})$ total nitrogen $\left(I_{\mathrm{N}}\right)$ and $(\mathrm{C})$ the $\mathrm{C}: \mathrm{N}$ ratio $\left(I_{\mathrm{C}: \mathrm{N}}\right)$ in 2 layers of the sediment ( 0 to 2.5 and 2.5 to $5 \mathrm{~mm}$ ). Means $\pm \mathrm{SD}$ (error bars) are shown $(\mathrm{n}=3)$

been extensively studied (Valiela et al. 1997). In our study, macroalgal biomass was in the low range of reported values for coastal environments, where the so-called 'green tides' frequently reach $<500 \mathrm{~g} \mathrm{DW} \mathrm{m}^{-2}$ (Valiela et al. 1997). In the Sancti Petri Channel, the low macroalgal biomass seems to be in correspondence with low concentrations of inorganic nutrients in the water column (Fig. 2). The chemical composition of this biomass changed seasonally (Fig. 3). Maximum tissue contents of $\mathrm{C}$ and $\mathrm{N}$ were measured in spring. During this season, the C:N ratio was at its lowest, suggesting more active growth. However, maximum contents of inorganic $\mathrm{N}$ were found at the end of autumn, when macroalgal biomass was lowest. The decrease in $\mathrm{C}: \mathrm{N}$ during spring was coincident with an increase in biomass after the winter and a decrease of stored inorganic nitrogen. Growth during this phase might have been partially supported by stored $\mathrm{N}$, since dissolved inorganic nitrogen in the water column was low during spring (Pedersen \& Borum 1996). In addition, rapid uptake of inorganic nitrogen mineralised in the sediment has been shown to support the growth of macroalgal blooms (Sundbäck et al. 2003).

\section{Oxygen concentration and net metabolism at the sediment-water interface}

The intertidal bare sediments of the Sancti Petri Channel were inhabited by a net autotrophic microbenthic community in every season (Fig. 6B). Metabolic rates of microbenthos $\left(P_{\mathrm{g}}, P_{\mathrm{n}}\right.$ and $\left.R_{\mathrm{d}}\right)$ were in accordance with previous studies including different techniques (Revsbech et al. 1981, MacIntyre et al. 1996). Maximum $P_{\mathrm{n}}$ and $P_{\mathrm{g}}$ rates were measured in spring, although the seasonal differences were not statistically significant, probably due to the high spatial heterogeneity of the sediment.

The macroalgal mat on the sediment increased the complexity and heterogeneity of the benthic-pelagic interface with respect to bare sediment, leading to irregularly shaped oxygen profiles due to (1) microscale spatial differences in the physiological state of macroalgae, which could lead to local differences in gross photosynthesis and respiration rates within the mat, and (2) the existence of channels and voids within the macroalgal mat allowing the advective transport of oxygen with the water flow. This was evident in many of our profiles, where we observed microzones within the mat in which $\mathrm{O}_{2}$ concentration was constant with depth. These channels were sometimes detected between 2 consecutive macroalgal fronds or between the macroalgal mat and the sediment surface. Very little is known about how water flow through the macroalgal mats in nature might affect its net metabolism and nutrient exchange with the water column (Krause-Jensen et al. 1999). Changes in the water turbulence and the physical structure (e.g. thickness, compactness) of the mat are likely to change the relative contributions of molecular diffusion and advective transport (Krause-Jensen et al. 1999, Dalsgaard 2003). This has methodological implications: the calculation of $P_{\mathrm{n}}$ and $R_{\mathrm{d}}$ from the microelectrode profiles at the DBL between the macroalgal mat and the water column would seriously underestimate the real rates, since the mass transfer between the mat and the water column does not occur exclusively by molecular diffusion. The methodological limitations could be similar to those applying to permeable sediments (Huettel \& Webster 2001). However, the application of the light-dark shift technique to measure $P_{\mathrm{g}}$ within the macroalgal mat is likely to be less problematic. Our results were only about $40 \%$ lower than those mea- 


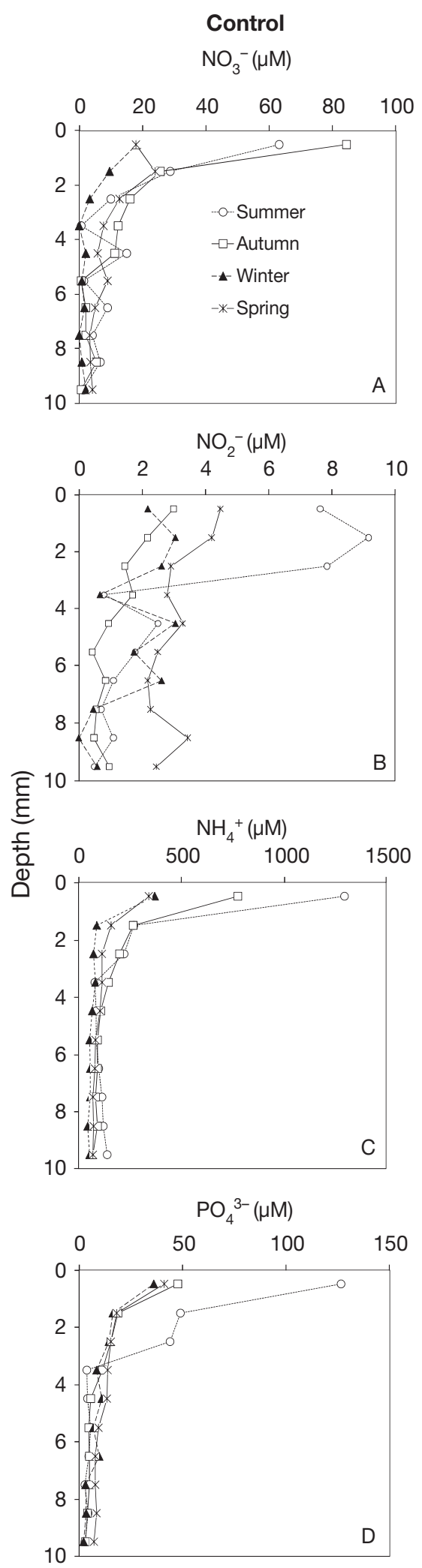

Control

$3(\mu \mathrm{M})$
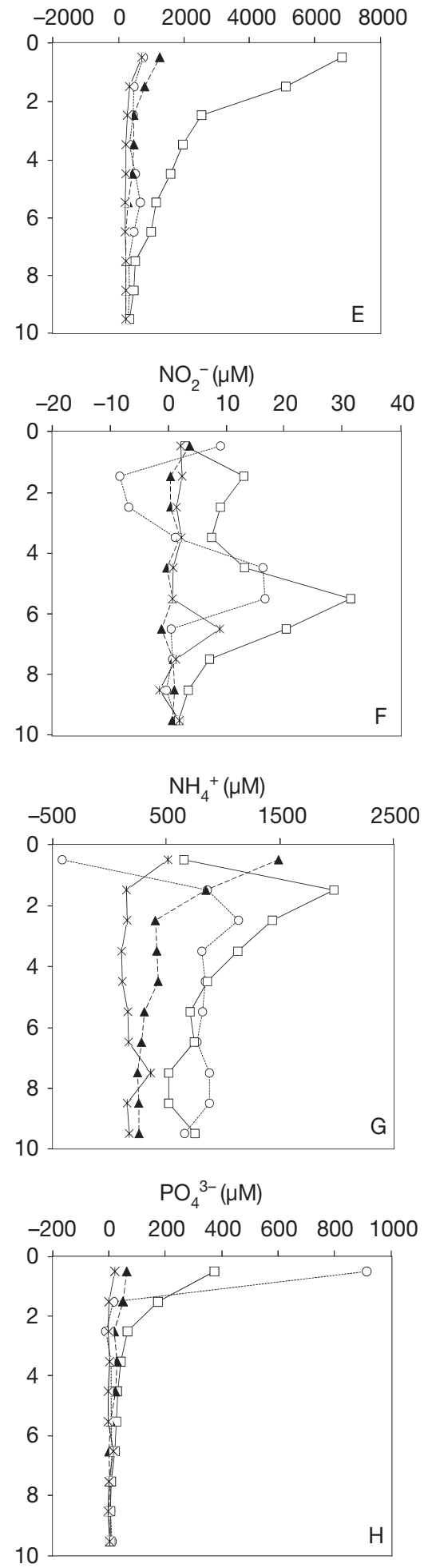

Fig. 9. (A-D) vertical profiles of freeze-lysable inorganic nutrients at the sediment surface in the absence of macroalgae (control). $(\mathrm{E}-\mathrm{H})$ increases observed under the influence of macroalgae (concentration with macroalgae minus concentration in the control) sured using benthic chambers, where it is assumed that respiration rates in the light and in the dark are the same (Hubas \& Davoult 2006). Moreover, the use of microelectrodes allowed us to show the microheterogeneity in the photosynthesis and respiration rates within the macroalgal mat (Fig. 4).

Macroalgae suppressed microphytobenthic photosynthesis likely by shading, changing the net metabolism of microbenthos from net autotrophic to fully heterotrophic. Under these conditions, macroalgae became the photoautotrophic component of the benthic community. Gross primary production almost doubled in the presence of macroalgae. Similar results have been obtained by others with different experimental approaches. Macroalgae increased $P_{\mathrm{g}} 2$ - to 7 -fold with respect to bare sediment in a field study with benthic chambers (Hubas \& Davoult 2006), 4- to 12 -fold in a laboratory study using a flow chamber (Dalsgaard 2003) and 4- to 7 -fold in outdoor microcosm incubations (McGlathery et al. 2001). Although macroalgae increased $P_{\mathrm{g}}$, both $P_{\mathrm{n}}$ and $R_{\mathrm{d}}$ were much lower than in bare sediment. But even assuming the underestimation of $P_{n}$, the macroalgal mat was always net autotrophic, since $P_{\mathrm{n}}$ was always positive in our study. On the contrary, Hubas \& Davoult (2006) found that macroalgal mat $P_{\mathrm{n}}$ was always higher than that of bare sediment, except in summer. In this season, benthic community respiration was highest, while $P_{\mathrm{g}}$ of macroalgae was lowest, leading to a heterotrophic $P: R$ ratio (Hubas \& Davoult 2006). However, in our study, $P_{\mathrm{n}}$ of the macroalgal mat was always positive, suggesting that our database does not include the senescence phase of the macroalgal bloom, where respiratory activity by the macroalgae themselves and the associated biota must be higher than photosynthetic $\mathrm{O}_{2}$ production. Nevertheless, even in healthy macroalgae, our data demonstrate on a microscale the existence of a diel cycle in $\mathrm{O}_{2}$ concentration and a considerable degree of microheterogeneity within the macroalgal mat. When macroalgae approach the senescence phase and the $P: R$ ratio decreases, the frequency and extension of hypoxic or anoxic microzones within the mat would increase. It has been 
suggested that hypoxic or anoxic conditions, created inside the mat during the night or below the mat's photic layer, might trigger the collapse of a bloom (Valiela et al. 1997, Nedergaard et al. 2002).

In the presence of macroalgae, the aerobic respiration rate $\left(R_{\mathrm{d}}\right)$ in the sediment was lower than that in the bare sediment (Fig. 6B, Table 1). This is explained by a decrease in $\mathrm{O}_{2}$ availability below the macroalgae, caused by a combination of several processes: inhibition of photosynthetic activity of the microphytobenthos, reduced mean water velocity below the macroalgae, the aerobic respiration of the macroalgae in the dark and an increase of organic matter input into the sediment. These effects would favour an increase in anaerobic processes like sulphate reduction. We detected $\mathrm{H}_{2} \mathrm{~S}$ in the sediment below the macroalgal mat, while it was not found in the control enclosures (Fig. 4). The balance between photosynthesis and respiration rates in the macroalgal canopy was a determinant for the $\mathrm{O}_{2}$ balance in the sediment. In the light, the photosynthetic $\mathrm{O}_{2}$ production by healthy macroalgae largely exceeded their own respiration, being an important source of oxygen for the sediment microbial community. This photosynthetic supply of oxygen alleviated its limiting effect upon the sediment aerobic respiration rate, increased the $\mathrm{O}_{2}$ penetration in the sediment and reduced the $\mathrm{H}_{2} \mathrm{~S}$ concentration within the sediment in the light (Figs. 4 \& 6B, Table 1). However, we never detected $\mathrm{H}_{2} \mathrm{~S}$ inside the macroalgal canopy (Nedergaard et al. 2002, Lomstein et al. 2006), likely because the macroalgal biomass was relatively low and it was net autotrophic during all seasons.

\section{$\mathrm{C}$ and $\mathrm{N}$ contents of the sediment}

Macroalgae significantly increased the mean annual contents of $\mathrm{C}$ and $\mathrm{N}$ of the sediment. However, the C:N ratio decreased due to a relatively higher increase in nitrogen. Similar results were observed during a $3 \mathrm{yr}$ study in the Swedish Skagerrak, but differences in C and $\mathrm{N}$ contents between sediment covered by algal mats and bare sediment were larger than in our study (Pihl et al. 1999). These increases in $\mathrm{C}$ and $\mathrm{N}$ below the macroalgal mat were likely to be the result of macroalgal production itself. Ephemeral green macroalgae are highly productive, and a substantial fraction of their production can be incorporated into the sediment (Owens \& Stewart 1983).

The input of organic matter into the sediment under the macroalgal mat is likely to be higher than that in bare sediments, and, in addition, its degradation rate might be lower. The presence of macroalgae might alter the decomposition rate of organic matter within the sediment, since they reduce the oxygen availability in, and the oxygen penetration depth into, the sediment, decreasing the fraction of organic matter being aerobically mineralised. Although controversial, the anaerobic decomposition of organic matter has been shown to be less efficient and to occur at a lower rate than aerobic decomposition, leading to a higher degree of organic carbon preservation within anoxic sediments (Hartnett et al. 1998). Furthermore, it is likely that differences in the stoichiometric C:N ratio between macroalgae and microphytobenthos also play a role in the observed increase of $\mathrm{C}$ and $\mathrm{N}$ contents of the sediment below the macroalgal mat. The annual mean C:N stoichiometric ratio of the macroalgal biomass was about 9.5, but higher values have frequently been reported for green macroalgae (Corzo \& Niell 1991, Duarte 1992). In general, degradability of organic matter is inversely related to its $\mathrm{C}: \mathrm{N}$ ratio, and therefore macroalgal detritus is more refractory than that of microphytobenthos (Enríquez et al. 1993).

The effect of macroalgae on the $\mathrm{C}$ and $\mathrm{N}$ contents and the $\mathrm{C}: \mathrm{N}$ ratio of the sediment changed seasonally (Fig. 8). In spring, the content of $\mathrm{C}$ and $\mathrm{N}$ in bare sediment was higher than below the macroalgal mat, likely due to a higher microphytobenthos biomass. The chlorophyll a concentration was higher in bare sediment than below the mat in spring (results not shown). In this season, microphytobenthos $P_{\mathrm{n}}$ was at its highest as well (Fig. 6B). In addition, macroalgae might remove $\mathrm{C}$ and $\mathrm{N}$ from the sediment with respect to the control, using $\mathrm{CO}_{2}$ and other inorganic nutrients (e.g. $\mathrm{N}, \mathrm{P})$ released from the sediment during the mineralisation of organic matter. It has been suggested that in this way the production of ephemeral green macroalgae could be self-regenerating (Lavery \& McComb 1991, Sundbäck et al. 2003).

\section{Accumulation of inorganic nutrients in the sediment}

The freeze-lysable inorganic nutrient fraction measured in the sediment contains both the nutrients dissolved in the pore water and the intracellular nutrients released due to cell breakage (Lomstein et al. 1990, Sayama 2001, Ferguson et al. 2004). The intracellular pool has been shown to represent most of the freezelysable fraction in the upper layer of the sediment ( 0 to $2 \mathrm{~mm}$ ), declining sharply with depth (Lomstein et al. 1990, Sayama 2001). The nutrient profiles measured in our study seem to agree with this pattern. In bare sediments, most of the freeze-lysable fraction of inorganic nutrients probably originated from microphytobenthic cells (Lomstein et al. 1990).

Macroalgae clearly increased the concentration of inorganic nutrients in the upper layer of the sediment (Fig. 9). In this case, an important contribution of 
microphytobenthos to the freeze-lysable fraction below the macroalgal mat is unlikely, since we showed that photosynthetic activity in the sediment below the macroalgae was inhibited. In addition, we observed a decrease in the abundance of microphytobenthos below the macroalgal mat during the same study (Corzo et al. 2005b). Intracellular inorganic nutrients of heterotrophic bacteria might contribute to the freezelysable fraction of sediments as well. However, most bacteria lack vacuoles and, therefore, are unable to store inorganic nutrients in large amounts. Only in sediment with abundant nitrate-accumulating sulphur bacteria, like Beggiatoa spp., which are able to store large amounts of nitrate in their vacuoles, has the intracellular pool been shown to be an important fraction of the freeze-lysable nitrate (Sayama 2001).

Green macroalgae are known to store large amounts of nitrate, ammonium and phosphate in their vacuoles (Corzo \& Niell 1992). Therefore, macroalgae might represent a source of inorganic nutrients for the sediment (Table 2). In the Sancti Petri Channel, macroalgae stored $5.68 \pm 1.53 \mathrm{mmol}$ nitrate $\mathrm{m}^{-2}, 7.95 \pm$ $0.76 \mathrm{mmol}$ ammonium $\mathrm{m}^{-2}$ and $7.39 \pm 3.87 \mathrm{mmol}$ phosphate $\mathrm{m}^{-2}$. The steep decline in sediment nutrient concentrations with depth clearly indicated that they were being incorporated into the sediment at the surface. The increase in inorganic nutrients was, in general, an order of magnitude lower than what would have been expected from the intracellular contents of macroalgae and their biomass (Table 2). A notable exception was the exceptionally high nitrate concentrations measured in the sediment in autumn. These high nitrate concentrations were likely to have been caused by a very recent input of macroalgal detritus to the sediment. Decomposition of macroalgal detritus induced a quick and transient increase in nitrate in the sediment during a microcosm experiment (Garcia-Robledo et al. 2008). The mass transfer from macroalgae to the sediment is expected to change with the physiological sta- tus of macroalgae. During the senescent phase, the collapse of the bloom is likely to transfer, in a short period of time, large amounts of $\mathrm{C}, \mathrm{N}$ and $\mathrm{P}$ to the sediment in the form of macroalgal debris (Garcia-Robledo et al. 2008). Healthy macroalgal mats might sustain a certain flux of debris to the sediment as well. The incorporation of this macroalgal debris, containing inorganic nutrients, to the sediment surface could explain the large amounts of freeze-lysable inorganic nitrogen and phosphate measured in the sediment below macroalgal mats. Likely, this explains the observed increases in total $\mathrm{C}$ and $\mathrm{N}$ as well.

The mineralisation of the bloom detritus and the growth of macroalgae could be closely connected due to the reutilization of released inorganic nutrients, as shown in the conceptual model presented in Fig. 10. During the first phase of degradation in the water column or at the sediment surface, soluble inorganic nutrients can be quickly released to the water column (Garcia-Robledo et al. 2008). In nature, intracellular nutrients directly released from decaying macroalgal debris to the water column could sustain the growth of the healthy macroalgae involved in the bloom. The degradation of particulate macroalgal detritus, once settled in the sediment, releases inorganic nutrients from the particulate fraction, increasing their concentration in the pore water. This increase induced a net nutrient efflux to the water column in the presence of decaying macroalgal detritus (Garcia-Robledo et al. 2008). A large fraction of remineralised nutrients in the sediment would be released to the water column when the microphytobenthos photosynthesis and growth is limited (Lorenzen et al. 1998, Dalsgaard 2003, GarciaRobledo et al. 2008). The increase of inorganic nitrogen in the pore water and the simultaneous inhibition of microphytobenthos demand, besides enhancing the efflux of inorganic nitrogen to the water column, might affect other microbial activities in the sediment, like nitrification and denitrification (Strauss \& Lamberti

Table 2. Inorganic nutrient contents in the tissue of macroalgae per unit surface area $\left(\mathrm{mmol} \mathrm{m}^{-2}\right)$, and the increase in nutrient contents in the first millimetre of sediment below the macroalgal mat $\left(\mathrm{mmol} \mathrm{m}^{-2}\right)$. The contents of inorganic nutrients in the macroalgae per unit surface area were calculated from the seasonal intracellular nutrient content and biomass. The increases in inorganic nutrients in the first millimetre of sediment in the presence of macroalgae were calculated from the increases in nutrients in the pore water (macroalga-control; Fig. 9), taking into account a mean water content in the sediment of $60 \%$ (765 ml pore water in a sediment layer of $1 \mathrm{~m}^{2}$ area and $1 \mathrm{~mm}$ thickness)

\begin{tabular}{|c|c|c|c|c|c|c|c|c|}
\hline & \multicolumn{2}{|c|}{$\longrightarrow$ Nitrate- } & \multicolumn{2}{|c|}{ Ammonium } & \multicolumn{2}{|c|}{$\longrightarrow$ Nitrite -} & \multicolumn{2}{|c|}{ Phosphate } \\
\hline & Macroalgae & Sediment & Macroalgae & Sediment & Macroalgae & Sediment & Macroalgae & Sediment \\
\hline Summer 2002 & 3.65 & 0.36 & 7.78 & -0.31 & 0.031 & 0.007 & 6.95 & 0.68 \\
\hline Autumn 2002 & 6.70 & 4.44 & 6.95 & 0.49 & 0.013 & 0.002 & 2.15 & 0.28 \\
\hline Winter 2003 & 7.03 & 0.71 & 8.55 & 1.11 & 0.031 & 0.003 & 9.42 & 0.05 \\
\hline Spring 2003 & 5.36 & 0.32 & 8.52 & 0.38 & 0.026 & 0.002 & 11.03 & 0.01 \\
\hline Mean \pm SD & $5.68 \pm 1.53$ & $1.46 \pm 1.99$ & $7.95 \pm 0.76$ & $0.42 \pm 0.58$ & $0.025 \pm 0.008$ & $0.003 \pm 0.002$ & $7.39 \pm 3.87$ & $0.26 \pm 0.31$ \\
\hline
\end{tabular}




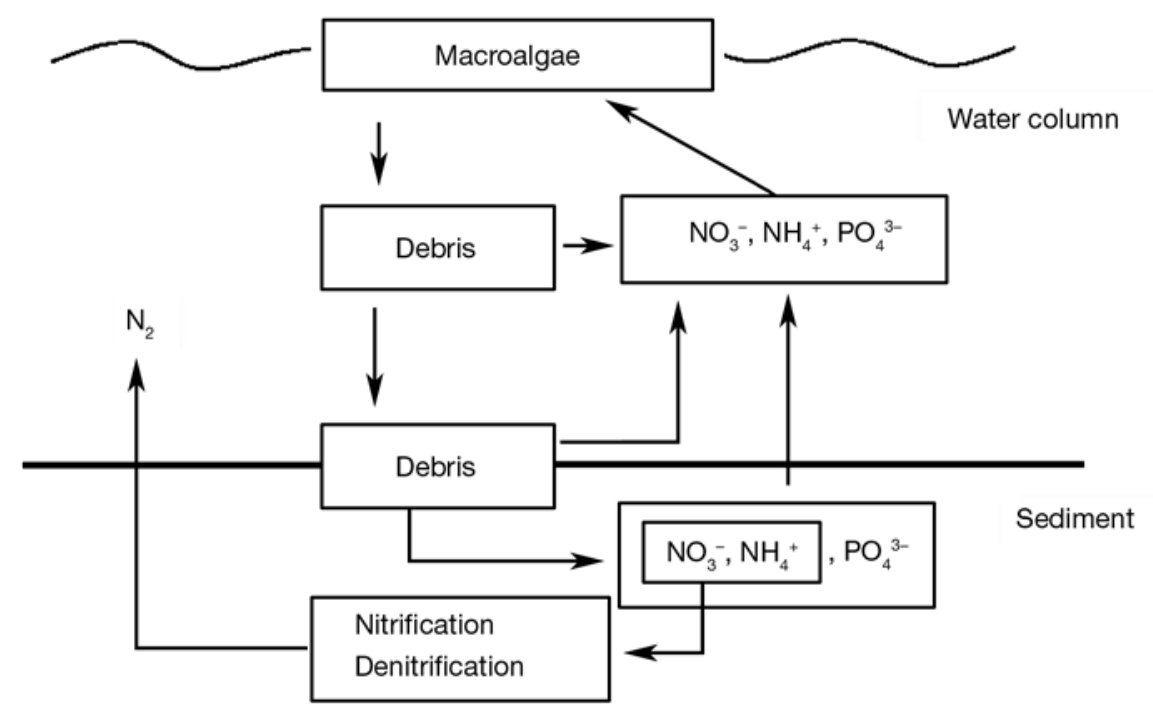

Fig. 10. Conceptual model of nutrient dynamics between macroalgae, the water column and the sediment during a macroalgal bloom

2000, Sundbäck \& Miles 2002, Dalsgaard 2003, Risgaard-Petersen 2003). Oxygen availability and oxygen penetration depth might determine what fraction of mineralised inorganic nitrogen within the sediment will be released to the water column and what fraction will be used for nitrification and denitrification. At least part of the nutrients that are released to the water column would be incorporated again by actively growing macroalgae, contributing to the self-regeneration of the bloom. This could be one of the mechanisms by which macroalgae are able to form dense blooms. What fraction of the inorganic $\mathrm{N}$ and $\mathrm{P}$ released from the sediment is captured by the macroalgae to sustain their growth? This is a difficult question to answer, since it will depend on the physiological state of macroalgae, the hydrodynamic conditions in situ and the proximity of macroalgae to the sediment surface, which changes with the tidal cycle. Sundbäck et al. (2003) estimated that the benthic efflux of regenerated inorganic nutrients could supply up to $55-100 \%$ of the nitrogen demand of macroalgae and up to $30-70 \%$ of the phosphorus demand.

Acknowledgements. We thank 4 anonymous reviewers for their suggestions and comments. This research was funded by Grants REN2002-01281/MAR and CTM 2006-04015 from The Ministerio de Educación y Ciencia, Spain. S. A. van Bergeijk was supported by a Marie Curie fellowship (HPMFCT-2000-00994) of the European Community and E. GarciaRobledo by a FPU grant (AP2005-4897) from Ministerio de Educación y Ciencia. We thank the staff of ACUINOVA S.A. for technical support and for providing us free access to the sampling site.

\section{LITERATURE CITED}

Corzo A, Niell FX (1991) C/N ratio in response to nitrogen supply and light quality in Ulva rigida C. Agardh. Sci Mar 55:405-411

Corzo A, Niell FX (1992) Inorganic nitrogen metabolism in Ulva rigida illuminated with blue light. Mar Biol 112: 223-228

Corzo A, Garcia de Lomas J, van Bergeijk SA, Luzon A, Mayayo MJ, Mata P (2005a) Carbonate mineralogy along a biogeochemical gradient in recent lacustrine sediments of Gallocanta Lake (Spain). Geomicrobiol J 22:283-298

Corzo A, van Bergeijk SA, Yufera M, García de Lomas J, García-Robledo E (2005b) Impact of macroalgal blooms on intertidal microbenthos: net metabolism, nutrient fluxes and community structure. In: Abstract Book, ASLO summer meeting 2005, Jun 19-24, Santiago de Compostela, p 35

Dalsgaard T (2003) Benthic primary production and nutrient cycling in sediments with benthic microalgae and transient accumulation of macroalgae. Limnol Oceanogr 48: $2138-2150$

Den Hartog C (1994) Suffocation of a littoral Zoostera bed by Entromorpha radiata. Aquat Bot 47:21-28

Duarte CM (1992) Nutrient concentration of aquatic plants: patterns across species. Limnol Oceanogr 37:882-889

> Enríquez S, Duarte CM, Sand-Jensen K (1993) Patterns in decomposition rates among photosynthetic organisms: the importance of detritus C:N:P content. Oecologia 94:457-471

Ferguson AJP, Eyre BD, Gay JM (2004) Benthic nutrient fluxes in euphotic sediments along shallow sub-tropical estuaries, northern New South Wales, Australia. Aquat Microb Ecol 37:219-235

Garcia-Robledo E, Corzo A, Garcia de Lomas J, Van Bergeijk SA (2008) Biogeochemical effects of macroalgal decomposition on intertidal microbenthos: a microcosm experiment. Mar Ecol Prog Ser 356:139-151

> Glud RN, Ramsing NB, Revsbech NP (1992) Photosynthesis and photosynthesis-coupled respiration in natural biofilms 
measured by the use of oxygen microsensors. J Phycol 28: $51-60$

Grasshoff K, Ehrhardt M, Kremling K (1983) Methods of sea water analysis. Verlag Chemie, Weinheim

Hartnett HE, Keil RG, Hedges JI, Devol AH (1998) Influence of oxygen exposure time on organic carbon preservation in continental margin sediments. Nature 391:572-574

Hayden HS, Blomster J, Maggs CA, Silva PC, Stanhope MJ, Waaland JR (2003) Linnaeus was right all along: Ulva and Enteromorpha are not distinct genera. Eur J Phycol 38: 277-294

Hubas C, Davoult D (2006) Does seasonal proliferation of Enteromorpha sp. affect the annual benthic metabolism of a small macrotidal estuary (Roscoff Aber Bay, France)? Estuar Coast Shelf Sci 70:287-296

Huettel M, Webster IT (2001) Porewater flow in permeable sediments. In: Boudreau BP, Jørgensen BB (eds) The benthic boundary layer. Oxford University Press, New York, p 144-179

Krause-Jensen D, Christensen PB, Rysgaard S (1999) Oxygen and nutrient dynamics within mats of the filamentous macroalga Chaetomorpha linum. Estuaries 22:31-38

Kühl M, Steuckart C, Eickert G, Jeroschewski P (1998) A $\mathrm{H}_{2} \mathrm{~S}$ microsensor for profiling biofilms and sediments: application in an acidic lake sediment. Aquat Microb Ecol 15: 201-209

Lavery PS, McComb AJ (1991) Macroalgal-Sediment Nutrient interactions and their importance to macroalgal nutrition in a eutrophic estuary. Estuar Coast Shelf Sci 32:281-295

Lomstein BA, Jensen MH, Sørensen J (1990) Intracellular $\mathrm{NH}_{4}{ }^{+}$and $\mathrm{NO}_{3}{ }^{-}$pools associated with deposited phytoplankton in a marine sediment (Aarhus Bight, Denmark). Mar Ecol Prog Ser 61:97-105

Lomstein BA, Guldberg LB, Neubauer ATA, Hansen J and others (2006) Benthic decomposition of Ulva lactuca: a controlled laboratory experiment. Aquat Bot 85:271-281

Lorenzen J, Glud RN, Revsbech NP (1995) Impact of microsensor caused changes in diffusive boundary layer thickness on $\mathrm{O}_{2}$ profiles and photosynthetic rates in benthic communities of microorganisms. Mar Ecol Prog Ser 119: $237-241$

Lorenzen J, Larsen LH, Kjær T, Revsbech NP (1998) Biosensor determination of the microscale distribution of nitrate, nitrate assimilation, nitrification, and denitrification in a diatom-inhabited freshwater sediment. Appl Environ Microbiol 64:3264-3269

MacIntyre HL, Geider RJ, Miller DC (1996) Microphytobenthos: the ecological role of the 'secret garden' of unvegetated, shallow-water marine habitats. I. Distribution, abundance and primary production. Estuaries 19:186-201

McGlathery KJ, Anderson IC, Tyler AC (2001) Magnitude and variability of benthic and pelagic metabolism in a temperate coastal lagoon. Mar Ecol Prog Ser 216:1-15

Middelburg JJ, Barranguet C, Boschker HTS, Herman PMJ, Moens T, Heip CHP (2000) The fate of intertidal microphytobenthos carbon: an in situ ${ }^{13} \mathrm{C}$-labeling study. Limnol Oceanogr 45:1224-1234

Nedergaard RI, Risgaard-Petersen N, Finster K (2002) The

Editorial responsibility: Hans Heinrich Janssen, Oldendorf/Luhe, Germany importance of sulfate reduction associated with Ulva lactuca thalli during decomposition: a mesocosm experiment. J Exp Mar Biol Ecol 275:15-29

> Norkko A, Bonsdorff E (1996) Rapid zoobenthic community responses to accumulations of drifting algae. Mar Ecol Prog Ser 131:143-157

- Owens NJP, Stewart WDP (1983) Enteromorpha and the cycling of nitrogen in a small estuary. Estuar Coast Shelf Sci 17:287-296

Pedersen MF, Borum J (1996) Nutrient control of algal growth in estuarine waters. Nutrient limitation and the importance of nitrogen requirements and nitrogen storage among phytoplankton and species of macroalgae. Mar Ecol Prog Ser 142:261-272

Pihl L, Svenson A, Moksnes P, Wennhage H (1999) Distribution of green algal mats throughout shallow soft bottoms of the Swedish Skagerrak archipelago in relation to nutrient sources and wave exposure. J Sea Res 41:281-294

Revsbech NP (1989) An oxygen microelectrode with a guard cathode. Limnol Oceanogr 34:474-478

Revsbech NP, Jørgensen BB (1983) Photosynthesis of benthic microflora measured with high spatial resolution by the oxygen microprofile method: capabilities and limitations of the method. Limnol Oceanogr 28:749-756

Revsbech NP, Jørgensen BB, Brix O (1981) Primary production of microalgae in sediments measured by oxygen microprofile, $\mathrm{H}_{14} \mathrm{CO}_{3}$-fixation, and oxygen exchange methods. Limnol Oceanogr 26:717-730

Risgaard-Petersen N (2003) Coupled nitrification-denitrification in autotrophic and heterotrophic estuarine sediments: on the influence of benthic microalgae. Limnol Oceanogr 48:93-105

Sayama M (2001) Presence of nitrate-accumulating sulfur bacteria and their influence on nitrogen cycling in a shallow coastal marine sediment. Appl Environ Microbiol 67: 3481-3487

Strauss EA, Lamberti GA (2000) Regulation of nitrification in aquatic sediments by organic carbon. Limnol Oceanogr 45:1854-1859

Sundbäck K, Miles A (2002) Role of microphytobenthos and denitrification for nutrient turnover in embayments with floating macroalgal mats: a spring situation. Aquat Microb Ecol 30:91-101

Sundbäck K, Jönsson B, Nilsson P, Lindström I (1990) Impact of accumulating drifting macroalgae on a shallow-water sediment system: an experimental study. Mar Ecol Prog Ser 58:261-274

Sundbäck K, Carlson L, Nilsson C, Jönsson B, Wulff A, Odmark S (1996) Response of benthic microbial mats to drifting green algal mats. Aquat Microb Ecol 10:195-208

Sundbäck K, Miles A, Hulth S, Pihl L, Engström P, Selander E, Svenson A (2003) Importance of benthic nutrient regeneration during initiation of macroalgal blooms in shallow bays. Mar Ecol Prog Ser 246:115-126

Valiela I, McClelland J, Hauxwell J, Behr PJ, Hersh D, Foreman K (1997) Macroalgal blooms in shallow estuaries: controls and ecophysiological and ecosystem consequences. Limnol Oceanogr 42:1105-1118

Submitted: July 16, 2008; Accepted: January 8, 2009

Proofs received from author(s): March 17, 2009 